\section{Tutkimustieto kumoaa työelämän myyttejä}

Pasi Pyöriä (toim.) (2017). Työelämän myytit ja todellisuus. Gaudeamus 2017. 250 sivua.

JULKISESSA KESKUSTELUSSA työelämän huonontumisesta on tullut itsestäänselvyys, joka pahimmillaan saattaa muodostua itseään toteuttavaksi ennusteeksi. Työelämän huonontumisesta puhutaan paljon, mutta kaikkia oletuksia ei voida tutkimuksella todentaa. Päinvastoin työelämätutkijoiden kirja tuo esille yllättävän paljon myönteisiä seikkoja työelämästä. Kirjassa työelämää lähestytään muun muassa Tilastokeskuksen työolotutkimusten sarjan pohjalta.

Asiantuntijoiden artikkeleista koostettu kirja avaa aihettaan monipuolisesti. Osansa saavat epätyypilliset työsuhteet, työn epävarmuus ja prekarisaatio, työhön sitoutuminen, nuoret työelämässä ja 24/7-yhteiskunta. Lisäksi tarkastellaan työn ja perheen yhteensovittamista, sukupuolten välistä tasa-arvoa, yrittäjyyttä, määräaikaisten ja vakinaisten työntekijöiden työoloja sekä työtaisteluja.

\section{TYÖELÄMÄN VAKAUS}

JA EPÄVARMUUS

Suomen työmarkkinoita suojaavat sopimisen kulttuuri ja kattava työelämän lainsäädäntö, mikä tekee työelämästä ennalta arvattavaa ja vakaata. Monilla työntekijöillä on hyvät vaikutusmahdollisuudet omaan työhönsä, ja työ on luonteeltaan itsenäistä.
Vaikka elämme ympärivuorokautisessa yhteiskunnassa, ja työntekijät ovat aiempaa helpommin tavoitettavissa, epätyypillisissä paikoissa työskentely on vähentynyt 2000-luvulla. Samoin on käynyt iltaisin ja viikonloppuisin työskentelylle, eivätkä etätyösopimukset ole lisänneet kotona työskentelyä. Työntekijät arvostavat yhtäältä työpaikan sosiaalisia suhteita ja toisaalta vapaa-aikaansa ja perhettään.

Kokoaikaisia työsuhteita on edelleen eniten, ja pätkätöiden määrä on pysynyt samana koko vuosikymmenen. Työmarkkinaratkaisut ja työehtosopimukset ovat taanneet hyvän työrauhan kymmenen viime vuoden aikana. Väitteitä työelämän pirstaloitumisesta ja siitä, että yhä useamman täytyy kouluttautua uuteen ammattiin, ei voi yleistää.

\section{PREKARIAATIN AHDINKO JATKUU}

Prekarisoituneeseen työelämään kuuluvat epävarmuus toimeentulosta ja epäluottamus työteon taloudellisesta kannattavuudesta. Kirjoittajien mukaan se on sekä ylikouluttautuneiden että haavoittuvassa asemassa olevien todellisuutta.

Vaikka työelämässä on yllättävän paljon pysyvyyttä, pelko työn menettämisestä on suuri. Enää ei

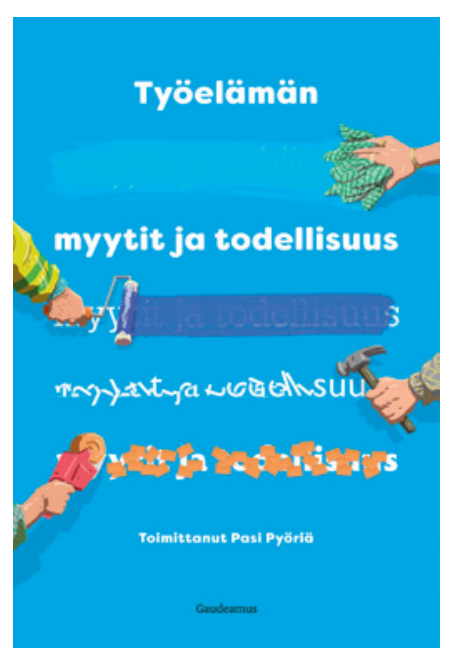

edes tiedetä, mitkä ammatit jatkuvat globaalissa kilpailussa, ja siksi työelämää on vaikea ennakoida. Pätkätyöllistymisenkin ongelmat ovat yhä ratkaisematta. Tutkijoiden mukaan kolmannes palkansaajista pelkää työttömyyttä, ja monen olisi vaikea työllistyä uudelleen, jos menettäisi työnsä.

Vaikka pätkätyöläiset ovat keskimääräistä paremmin kouluttautuneita ja jopa hiukan terveempiä kuin vakituisessa työsuhteessa olevat, moni tekee pätkätöitä vasten tahtoaan, ja tulot jäävät liian usein pieniksi. Sosiaaliturvajärjestelmällemme onkin suuri haaste ratkaista, miten tulevaisuudessa voidaan yhdistää pienipalkkainen työ ja sosiaalietuudet. Yrittäjät tekevät keskimäärin pidempää työpäivää kuin muut palkansaajat.

Nuoriin kohdistuneet moraaliset epäilyt työnteon arvostuksesta eivät saa tutkijoilta vahvistusta, eikä eri sukupolvien välisessä ajankäytössä ole eroja. Työelämän haasteista kiire rasittaa erityisesti lapsiperheiden vanhempia 
ja julkisen sektorin työntekijöitä. Tarvitaankin avointa keskustelua eri ammattiryhmien työoloista, eri toimialojen tulevaisuudesta ja osaamistarpeista.

\section{PIILOINEN SYRJINTÄ}

ON KARSITTAVA

Kirjoittajat tuovat esille, että kansainvälisessä vertailussa asiat ovat Suomessa hyvin, mutta yhä kaivataan käytännön toimia, joilla karsia työyhteisöistä syrjinnälle altistavia piileviä asenteita. Tasa-arvoa koskevissa asioissa tarvitaan lisää kokeiluja.

Työn ja perheen yhteensovittamiseen sisältyy haasteita: vanhem- piin kohdistuu yhä enemmän odotuksia, kun kaikki asiat halutaan tehdä mahdollisimman hyvin. Kun teknologia mahdollistaa samanaikaisuuden, työ ja vapaaaika limittyvät, mikä kuormittaa etenkin naisia ja saa aikaan tunteen, että työ on läsnä koko ajan.

Työelämän kielteistä julkikuvaa ja sitä koskevaa tuoretta tutkimustietoa katsotaan kirjassa yhteiskuntatieteen näkökulmasta pikemminkin menneen kuin tulevan kannalta. Vielä emme esimerkiksi tiedä, millaisia uusia työpaikkoja yhteiskuntaamme syntyy. Emme myöskään voi arvioita, miten koulutukseen kohdistuneet mittavat leikkaukset vaikuttavat tulevaisuuteen ja säilyykö koulutus suomalaisena menestystarinana.

Omat oletukseni työelämän muuttumisesta yhä haasteellisemmaksi eivät saaneet kirjasta tieteellistä tukea, mutta näkökulmani työelämään laajeni. Vaikka palkansaajien ja yrittäjien enemmistö voi hyvin ja on tyytyväisiä työhönsä, kirja antaa äänen subjektiivisille kokemuksille ja tunteille työelämän muutoksista. Siten se tekee kokemuksista todempia.

SANNA JUVONEN

$\mathrm{KM}$, lehtori

Laurea-ammattikorkeakoulu 